\title{
MIRANDA IN THE MODERN SCHOOL: THE BLURRY APPLICATION OF A BRIGHT-Line RULE
}

\author{
RAELYNN CHASTAIN*
}

\section{INTRODUCTION}

In the modern school environment where criminal activities such as school shootings, bomb threats, sexual harassment, and drug use are not uncommon, there is a growing number of resource officers in schools. ${ }^{1}$ Due to the increasing police presence, the line between questioning for school disciplinary purposes and custodial interrogation that may result in criminal charges continues to blur. ${ }^{2}$ By default, students - most of whom are minors - pay the potentially hefty price for schools and officers' uncertainty, because students' individual rights and constitutional freedoms are those at risk. ${ }^{3}$

One of the most prominent constitutional rights in jeopardy is the Fifth Amendment right against self-incrimination, which the United States Supreme Court famously addressed in Miranda v. Arizona. ${ }^{4}$ The Court deemed Miranda warnings a necessary procedural safeguard to upholding individuals' Fifth Amendment rights. ${ }^{5}$ Miranda warnings have become common practice since the Supreme Court's landmark decision, but courts across the country have widened Miranda's scope in the decades since then - especially within schools. ${ }^{6}$ In recent years, the educational environment has undergone significant changes, leading more schools to employ full-time officers. ${ }^{7}$ Due to the modern school atmosphere, it is vital for courts across the nation to address students' Fifth Amendment rights within schools and the evidentiary and policy impacts of Miranda warnings in schools.

While recent school shootings spurred Congress to encourage schools to employ officers as guards, police presence within schools is not a new concept. ${ }^{8}$ In fact, the number of school resource officers has steadily risen for years. ${ }^{9}$ The

* J.D., Indiana University Robert H. McKinney School of Law, 2020; B.S., Indiana University Purdue University Indianapolis - Indianapolis, Public Affairs, 2017.

1. Melissa Diliberti et al., Crime, Violence, Discipline, and Safety in U.S. Public Schools: Findings From the School Survey on Crime and Safety: 2015-16, U.S. DeP'T OF EdUC., NAT'L CTR. FOR EDUC., July 2017, at 6-15.

2. Lisa H. Thurau \& Johanna Wald, Controlling Partners: When Law Enforcement Meets Discipline in Public Schools, 54 N.Y.L. ScH. L. REV. 977 (2010).

3. Id.

4. Miranda v. Arizona, 384 U.S. 436, 444 (1966).

5. $I d$.

6. Catherine Y. Kim, Policing School Discipline, 77 BrooK. L. ReV. 861 (2012).

7. Id. at 862 .

8. David Sherfinski, Percentage of Public Schools with Resource Officers on the Rise: Report, The WAshington Times (Mar. 29, 2018), https:/www.washingtontimes.com/news/2018/ mar/29/percentage-public-schools-resource-officers-rise-r/ [https://perma.cc/KB9Z-B5L9].

9. Id. 
National Center for Education Statistics reported that " $42 \%$ percent of schools [already] had a resource officer on site in the 2015-2016 school year," a 10percent increase from the previous decade. ${ }^{10}$ After seventeen lives were lost in a mass school shooting at Marjory Stoneman Douglas High School in Parkland, Florida, ${ }^{11}$ Mo Canady, the executive director of the National Association of School Resource Officers, predicted another surge in the number of school officers. ${ }^{12}$ The increasing number of on-site police "has led to the criminalization of behavior" which school administrators previously would have addressed. ${ }^{13}$

Thirteen-year-old B.A. got caught in the middle of this constitutional issue when he was removed from his bus and taken to the vice principal's office for questioning regarding a bomb threat found on the school's bathroom wall. ${ }^{14}$ The vice principal conducted the interview, while three uniformed officers hovered and encouraged B.A. to confess - but B.A. was never given a Miranda warning. ${ }^{15}$ After B.A. was reduced to tears, the interrogation ended, and only then was his mother called; when she arrived, B.A. admitted that he wrote the threat as a joke. $^{16}$

Following this un-Mirandized admission, the school resource officers arrested B.A, and the State filed a petition alleging that B.A. had "committed false reporting, a Level 6 felony if committed by an adult, and institutional criminal mischief, a Class A misdemeanor if committed by an adult." ${ }^{17}$ At trial, B.A. moved to suppress his incriminating statements, "arguing that he was entitled to Miranda warnings ... and that officers failed to secure a waiver of his Miranda rights under Indiana's juvenile waiver statute."18 But, "the juvenile court denied the motion and found B.A. delinquent on both counts."19

On appeal, the Indiana Supreme Court held that the scenario in B.A. v. State required a Miranda warning, because the student was under custodial interrogation. ${ }^{20}$ But in its sister case, D.Z. v. State, the Court found that a Miranda warning was not necessary, because the student was not under custodial interrogation since only the assistant principal, not acting as an agent of a school officer, interviewed the student. ${ }^{21}$

10. Id.

11. Elizabeth Chuck et al., 17 Killed in Mass Shooting at High School in Parkland, Florida, NBC NEws (Feb. 14, 2018, 3:18 PM), https:/www.nbcnews.com/news/us-news/police-respondshooting-parkland-florida-high-school-n848101 [https://perma.cc/J2LR-6RVL].

12. Sherfinski, supra note 8 .

13. James Carey, A Student's Right to Remain Silent, 43 J.L. \& EduC. 575, 576 (2014).

14. B.A. v. State, 100 N.E.3d 225, 228 (Ind. 2018).

15. Id.

16. Id.

17. Id.

18. Id. at 228; IND. CODE $\S 31-32-5-1$ (2017).

19. B.A., 100 N.E.3d at 228 .

20. Id.

21. D.Z. v. State, 100 N.E.3d 246, 247 (Ind. 2018) (finding that because the assistant principal questioned the student with no officer present, Miranda warnings were not required, even 
While the United States Supreme Court was clear in Miranda that the warning requirement hinges upon whether an individual is in custody during the time of interrogation, ${ }^{22}$ the parameters of what constitutes custodial interrogation within a school setting remain unclear. Seven years prior to the recent Indiana cases, the United States Supreme Court weighed in on a specific portion of the custodial interrogation analysis within schools that triggers the need for a Miranda warning - age in relation to the reasonable person standard. ${ }^{23}$ In J.D.B. v. North Carolina, the Court recognized an additional factor under the Miranda analysis when it held that a minor's age may be relevant to the custodial determination. ${ }^{24}$ Following this decision, many states - including Indiana-have struggled to apply a clear standard when determining whether an in-school interrogation changes into a custodial interrogation. ${ }^{25}$ While students, juvenile or adult, do not shed their constitutional rights at the schoolhouse gate, ${ }^{26}$ courts must find a way to balance students' rights with schools' need to discipline and maintain a safe and orderly educational environment.

This Note addresses the ambiguity in Indiana's most recent pair of Supreme Court decisions regarding Miranda warnings in schools. Additionally, this Note considers the strengths and shortcomings of potential resolutions that seek to clarify the delicate balance between students' Fifth Amendment rights and school officials' and school resource officers' ability to discipline and maintain a safe educational environment.

Part I of this Note discusses the custodial analysis with regard to in-school interrogations and addresses two reasons why a unique custodial analysis should be required: (1) the increased risk of coercion in the schoolhouse setting and (2) the need for a reasonable child objective standard. Part II analyzes the implications of Indiana's two recent Supreme Court decisions, D.Z. v. State and B.A. v. State, which portrayed two contrasting examples of Miranda in the school setting, while still leaving room for debate on the custody determination standard. ${ }^{27}$ Part III of this Note compares Indiana's rule regarding Miranda warnings in schools to practices in other states and analyzes how effective each state's rule would be if implemented in Indiana. Part IV examines important policy considerations that judges, legislators, and school administrators must consider when implementing policies regarding Miranda warnings in schools. Finally, Part V discusses the strengths and weaknesses of six bright-line resolutions to the issue set forth in this Note and ultimately advocates for the

though the assistant principal later told the school officer of the student's confession).

22. Miranda v. Arizona, 384 U.S. 436, 478-79 (1966).

23. See J.D.B. v. North Carolina, 564 U.S. 261 (2011).

24. Id. at 277.

25. Sally Terry Green, A Presumptive In-Custody Analysis to Police-Conducted School Interrogations, 40 AM. J. CRIM. L. 145 (2013); J.D.B., 564 U.S. at 281-82 (Alito, J., dissenting) ("[The Court's decision] is fundamentally inconsistent with one of the main justifications for the Miranda rule: the perceived need for a clear rule that can be easily applied in all cases.").

26. Tinker v. Des Moines Indep. Cmty. Sch. Dist., 393 U.S. 503, 506 (1969).

27. See D.Z. v. State, 100 N.E.3d 246 (Ind. 2018); B.A. v. State, 100 N.E.3d 225 (Ind. 2018). 
Kentucky approach.

\section{DEFINING CUSTODY}

In Miranda $v$. Arizona, the Court defined custodial interrogation as "questioning initiated by law enforcement officers after a person has been taken into custody or otherwise deprived of his freedom of action in any significant way." ${ }^{28}$ Traditionally, courts consider two factors when determining whether an individual is in custody: (1) "the circumstances surrounding the interrogation," and (2) given those circumstances, whether a reasonable person would feel able to end the interrogation and leave. ${ }^{29}$ Courts still consider these two factors when determining whether a student is in custody, but the special circumstances created by the nature of the school setting complicate this analysis. ${ }^{30}$ The two biggest issues that courts must confront regarding the in-school custodial determination are the increased risk of coercion in the school setting and the unique factor that a child's age plays in the reasonable person analysis. ${ }^{31}$

Section A analyzes how the increased risk of coercion in the school setting affects the way students respond to questioning from school officers or administrators. ${ }^{32}$ Section B discusses why a distinct "reasonable child" standard should be applied to juveniles when determining whether they are in custody, because, as the Supreme Court held in J.D.B. v. North Carolina, age is relevant. ${ }^{33}$

\section{A. The Increased Risk of Coercion in the School Setting}

When considering the first factor of the custody analysis - the circumstances surrounding the interrogation - courts should recognize the unique nature of interrogation in the schoolhouse setting. ${ }^{34}$ This analysis focuses on the student's perceptions, not police intent, ${ }^{35}$ and emphasizes the commonsense differences between children's and adults' behavior and perceptions that are "self-evident to anyone who was a child once himself, including any police officer or judge." 36 There are two distinct reasons why children have an increased risk of coercion in the school setting; first, students do not feel free to leave the room due to their reduced rights within schools. ${ }^{37}$ And second, juveniles lack knowledge of the potential legal penalties that could result from a seemingly innocuous in-school interrogation. ${ }^{38}$

28. Miranda v. Arizona, 384 U.S. 436, 444 (1966).

29. Thompson v. Keohane, 516 U.S. 99, 112 (1995).

30. Green, supra note 25, at 146.

31. Id.

32. Id.

33. J.D.B. v. North Carolina, 564 U.S. 261, 272 (2011).

34. Green, supra note 25 , at 154.

35. Rhode Island v. Innis, 446 U.S. 291, 301 (1980).

36. J.D.B., 564 U.S. at 272.

37. Green, supra note 25, at 154.

38. Id. at 172 . 
1. Juveniles Do Not Feel Free to Leave Due to Their Diminished Rights in Schools.-Students already have Supreme Court-approved diminished rights in public schools, such as limited rights against search and seizure, limited free speech rights, strict discipline codes, and heightened security measures. ${ }^{39}$ Unlike adults, juveniles "are always in some form of custody," whether at school or at home. ${ }^{40}$ This constant in-custody status greatly influences how minors perceive the world and their ability to move freely within it. ${ }^{41}$ For example, there are compulsory attendance laws for school-aged children, so based on their required attendance, "it is reasonable for a student to think he is not free to leave" the principal's office during questioning. ${ }^{42}$

In-school interrogations create unique circumstances that are fundamentally "coercive and custodial in nature." 43 Freedom of movement is inherently restricted in the school setting due to school rules and policies for student conduct. ${ }^{44}$ Schools often require students to remain in the classroom and do not permit them to leave the building, roam the halls, or even go to the restroom without permission from an authority figure. ${ }^{45}$ Due to such school policies, students have often been removed from their location and escorted to the interview setting by an officer or administrator. ${ }^{46}$ So of course, after being escorted or called down to the principal's office, no reasonable student feels free to simply walk out. ${ }^{47}$ In fact, students "might mistakenly believe that if they comply with school rules and cooperate during [an] interrogation, then they will be able to return to class without" additional consequences. ${ }^{48}$

Other state supreme courts have found that whether juveniles are told they are free to leave is crucial to the custody analysis. ${ }^{49}$ In B.A., the Indiana Supreme Court agreed that when considering the circumstances surrounding the custody analysis, notice of freedom to leave plays a major role. ${ }^{50}$ This factor weighed heavily against the school and officers in B.A., because the student was never told he was "free to call his mother, leave the room, take a break, or go to class." 51 Due to the inherent restricted freedom of movement within schools, the

39. Kerrin C. Wolf, Assessing Students' Civil Rights Claims Against School Resource Officers, 38 PACE L. REV. 215, 226 (2018).

40. Schall v. Martin, 467 U.S. 253, 265 (1984) (internal citations omitted).

41. Id. ("Children, by definition, are not assumed to have the capacity to take care of themselves. They are assumed to be subject to the control of their parents, and if parental control falters, the State must play its part as parens patriae.")

42. Carey, supra note 13, at 577.

43. Green, supra note 25 , at 154.

44. Id. at 160-61.

45. T.S. v. State, 863 N.E.2d 362, 372 (Ind. Ct. App. 2007).

46. Green, supra note 25, at 160-61.

47. B.A. v. State, 100 N.E.3d 225, 232 (Ind. 2018).

48. Green, supra note 25, at 156.

49. State v. C.H., 763 N.W.2d 708, 715 (Neb. 2009).

50. B.A., 100 N.E.3d at 234 .

51. Id. 
potentially mistaken belief that compliance with authority will avoid further consequences, and the lack of notice to students of the ability to leave, the school setting presents a higher risk of coercion than interrogations conducted outside the school. ${ }^{52}$ But even if the student did feel free to leave the room, juveniles still lack the legal knowledge to be able to protect their rights and comprehend the potential consequences of the interaction. ${ }^{53}$

2. Juveniles Lack the Knowledge of Potential Legal Consequences.Juveniles, who have not yet completed their basic education, cannot be expected to know the inner workings of the legal system and the possible penalties they may face ${ }^{54}$ for conduct they often consider innocent mischief, not criminal behavior. Students are often not aware of the potential criminal prosecution that could result from statements they make during an interrogation, and they can easily be misled into believing that their statements will not result in legal consequences. $^{55} \mathrm{~A}$ child is "not equal to the police in knowledge and understanding of the consequences of the questions and answers being recorded" and is "unable to know how to protect his own interests or how to get the benefits of his constitutional rights." ${ }^{56}$ Without advisement, juveniles have no way of knowing the legal effects of their confessions. ${ }^{57}$

With the increased risk of coercion and lack of knowledge comes the increased risk of false confessions. ${ }^{58}$ Miranda's premise is that "the interaction of custody and official interrogation" produces the risk of coercion, which may result in false confessions. ${ }^{59}$ Adults are susceptible to the physical and psychological isolation of custodial interrogation and can be compelled into speaking when they otherwise would not speak freely. ${ }^{60}$ Because adults are so vulnerable to this immense pressure that "it can induce a frighteningly high percentage of people to confess to crimes they never committed," then it can only follow that children experience just as severe, if not more, pressure to submit to police questioning. ${ }^{61}$

If logic is not convincing enough, research supports this notion that children are more susceptible to police interrogations than adults. ${ }^{62}$ Recent studies

52. See supra Part I.A.1.

53. Gallegos v. Colorado, 370 U.S. 49, 54 (1962).

54. See id.

55. See Green, supra note 25 , at 146, 172.

56. Gallegos v. Colorado, 370 U.S. 49, 54 (1962).

57. Id.

58. Corley v. United States, 556 U.S. 303, 320-21 (2009) (citing Steven Drizin \& Richard Leo, The Problem of False Confessions in the Post-DNA World, 82 N.C. L. REV. 891, 906-07 (2004)).

59. Illinois v. Perkins, 496 U.S. 292, 297 (1990).

60. J.D.B. v. North Carolina, 564 U.S. 261, 269 (2011).

61. Corley, 556 U.S. at 321 (citing Steven Drizin \& Richard Leo, The Problem of False Confessions in the Post-DNA World, 82 N.C. L. REV. 891, 906-07 (2004)).

62. Joshua A. Tepfer et al., Arresting Development: Convictions of Innocent Youth, 62 RutGers L. REV. 887, 904 (2010). 
demonstrate that "youth are particularly likely to react to pressure-filled interrogation by falsely confessing." ${ }^{63}$ Data shows that 31.1 percent of juvenile exonerees were wrongfully convicted based on a false confession, where only 17.8 percent of adults exonerees were wrongfully convicted based on a false confession. $^{64}$ And a staggering 93.75 percent of the juveniles exonerated following a false confession gave the false confession during police interrogation. ${ }^{65}$ These high statistics of false confessions could be attributed to juveniles' greater desire than adults to comply with authority figures such as school principals, vice principals, or resource officers. ${ }^{66}$ Juveniles are already inclined to comply with authority figures, and this vulnerability is only heightened when police officers are present; police "often occupy an elevated position of power relative to children." ${ }^{\prime 67}$

Even the lack of police presence does not automatically indicate that the student was not in custody for Miranda purposes.$^{68}$ If school administrators are acting as agents of the police, then the custodial interrogation analysis is still required. ${ }^{69}$ But because coercion "is determined from the perspective of the suspect," an agency relationship requires Miranda warnings only if the suspect is aware of the underlying police involvement, enough that it creates a "coercive atmosphere." ${ }^{70}$

Because juveniles inherently do not feel free to leave the room during an interrogation and they lack the legal knowledge and maturity to combat the pressures presented by the unequal balance of power, there is a heightened risk of coercion during in-school interrogations that courts must take into account. In addition to the increased risk of coercion, courts must consider the reasonable child standard before making the custody determination.

\section{B. The Reasonable Child Standard}

Until recently, the same objective standard was applied to adults and juveniles, but in J.D.B. v. North Carolina, the United States Supreme Court held that age may be considered when determining the circumstances of the interrogation. ${ }^{71}$ This additional piece of the custody analysis does not undermine the standard's objectivity, because "a child's age differs from other personal characteristics that, even when known to police, have no objectively discernible

63. Id. at 893.

64. Id. at 904 .

65. Id.

66. Kristi North, Recess is Over: Granting Miranda Rights to Students Interrogated Inside School Walls, 62 EMORY L.J. 441, 467 (2012).

67. Barbara Kaban \& Ann E. Tobey, When Police Question Children: Are Protections Adequate?, 1 J. CTR. FOR CHILD. \& CTS. 151, 155 (1999).

68. D.Z. v. State, 100 N.E.3d 246, 248 (Ind. 2018).

69. Id.

70. Illinois v. Perkins, 496 U.S. 292, 296 (1990).

71. Id. at 277 . 
relationship to a reasonable person's understanding of his freedom of action.",72 The Court held that when officers either know the child's age at the time of interrogation, or the child's age is objectively apparent to a reasonable officer, age is relevant to the custody analysis. ${ }^{73}$ Age is pertinent, because, due to a minor's inherent immaturity, a reasonable child subjected to police questioning might feel greater pressure to acquiesce in a situation where a reasonable adult would feel free to leave. ${ }^{74}$

However, Justice Alito argued in his dissent to J.D.B. that the new reasonable child standard is not as clear and easily applicable as Miranda requires. ${ }^{75} \mathrm{He}$ wrote, "Miranda's prophylactic regime places a high value on clarity and certainty." "The dissent argues that the majority's decision shifts the "one-sizefits-all reasonable-person test into an inquiry that must account for at least one individualized characteristic - age." ${ }^{, 77}$

But a juvenile's age is far "more than a chronological fact"; it is a maturity issue. ${ }^{78}$ Courts should implement the reasonable child standard into the custody determination, because the law historically differentiates children from adults, and children's undeveloped brains affect the way they perceive interrogations within the school setting.

1. The Law Historically Differentiates Children from Adults.-The Supreme Court has repeatedly emphasized the realistic difference between children and the reasonable adult. ${ }^{79}$ In Eddings v. Oklahoma, the Court highlighted a long history of statutes and judicial decisions that recognize that children cannot be treated simply as miniature adults ${ }^{80}$ Children "often lack the experience, perspective, and judgment to recognize and avoid choices that could be detrimental to them." This makes juveniles "more vulnerable or susceptible to . . . outside pressures" than adults. ${ }^{82}$ For example, in Roper v. Simmons, the Court, relying on scientific and sociological studies that point to juveniles' lack of maturity, underdeveloped sense of responsibility, and susceptibility to negative influences, struck down the death penalty for adolescents. ${ }^{83}$ And in Graham v. Florida, the Court held that due to a lack of maturity, which often results in impulsive decisions, juveniles should not be sentenced to life without parole for any crime, other than homicide. ${ }^{84}$ Furthermore, in J.D.B., the Court found no reason why police officers

72. Id. at 275 .

73. Id. at 277 .

74. Id. at 272 .

75. Id. at 281-82 (Alito, J., dissenting).

76. Id. at 282 (Alito, J., dissenting).

77. Id. at 283 (Alito, J., dissenting).

78. Eddings v. Oklahoma, 455 U.S. 104, 115 (1982).

79. J.D.B. v. North Carolina, 564 U.S. 261, 272 (2011).

80. Eddings, 455 U.S. at 115-16.

81. Bellotti v. Baird, 443 U.S. 622, 635 (1979).

82. Roper v. Simmons, 543 U.S. 551, 569 (2005).

83. Id. at 569-74.

84. Graham v. Florida, 560 U.S. 48, 71-72 (2010). 
and courts must turn a blind eye to the reality that children often feel forced to submit to police questioning in situations where an adult would feel free to leave. ${ }^{85}$

The law historically reflects this assumption that children typically lack the ability to exercise mature judgment. ${ }^{86}$ For example, laws limit children's ability to purchase property, enter into binding contracts, and marry without parental consent. ${ }^{87}$ Even where a reasonable person standard applies, the common law recognizes that juveniles are not equivalent to adults. ${ }^{88}$ In negligence suits, where liability is based on what an objectively reasonable person would do under the circumstances, "[a]ll American jurisdictions accept the idea that a person's childhood is a relevant circumstance." ${ }^{\prime 9}$ Like the courts have recurrently stated, the law exhibits "the settled understanding that the differentiating characteristics of youth are universal." ${ }^{\prime 0}$ This historic assumption that children must be treated distinctively from adults under the law is not based simply on tradition-scientific research confirms this longstanding belief.

2. Juveniles' Undeveloped Brains Affect Their Perception.- Science verifies the courts and legislators' established assumption that children and adults cannot be treated identically under the law. ${ }^{91}$ Neuroscience reveals that brain development plays a major role in juveniles' abilities to make mature decisions during an interrogation. ${ }^{92}$ The prefrontal cortex, an area of the brain that is not fully developed until adulthood, affects adolescents' "ability to inhibit impulses, weigh consequences of decisions, prioritize, and strategize." 93 Due to an underdeveloped brain and judgment center, juveniles are more likely to make short-sighted decisions that result in what they perceive as the reward-being allowed to go home or back to class, avoiding jail, or ending the questioning as quickly as possible - without regard for the long-term risks associated with that decision. $^{94}$ If the law disregards these relevant developmental concerns by applying the same reasonable person standard to juveniles as it does to adults, it does juveniles a disservice by undervaluing the negative impact such a standard can have on their constitutional rights. ${ }^{95}$

85. J.D.B. v. North Carolina, 564 U.S. 261, 264-65 (2011).

86. Id. at 273 .

87. Id.

88. Id. at 274 .

89. Restatement (Third) of Torts $\S 10 \mathrm{cmt}$. b (Am. Law Inst. 2010).

90. J.D.B., 564 U.S. at 273.

91. Id.

92. Id.

93. Jay N. Giedd, Structural Magnetic Resonance Imaging of the Adolescent Brain, 1021 ANNALS N.Y. ACAD. SCI. 77, 83 (2004).

94. Christine S. Scott-Hayward, Explaining Juvenile False Confessions: Adolescent Development and Police Interrogation, 31 LAW \& Psychol. Rev. 53, 55 (2007).

95. See Marsha L. Levick \& Elizabeth-Ann Tierney, The United States Supreme Court Adopts a Reasonable Juvenile Standard in J.D.B. v. North Carolina for Purposes of the Miranda Custody Analysis: Can a More Reasoned Justice System for Juveniles Be Far Behind?, 47 HARV. 
Logic requires that courts apply a distinct reasonable child standard to students within schools for custodial analysis purposes, because students have unique experiences and perceptions that are incomparable to adults' experiences and perceptions in their world outside the school setting. ${ }^{96}$ For example, it is illogical to analyze how a reasonable adult would react to being removed from class by a uniformed officer and taken into the vice principal's office for questioning, because this is a circumstance that, by its nature, is specific to children. ${ }^{97}$ This unique effect of the school setting on juveniles "cannot be disentangled from the identity of the person questioned"; therefore, the custodial interrogation analysis requires the use of a reasonable child standard that is different from the standard applied to adults. ${ }^{98}$

Even when officers do not speak, their mere presence creates a coercive environment where a reasonable student, overwhelmed by police and school officials, may feel compelled to respond to questioning. ${ }^{99}$ During police interrogation, events that "would leave a man cold and unimpressed can overawe and overwhelm a lad in his early teens." ${ }^{100}$ Students observe how their school officials cooperate and rely on law enforcement to further their goals; this creates confusion when students are subjected to questioning, because they may no longer believe that the interrogation is aimed at students' welfare and determining whether school rules were broken. ${ }^{101}$ Instead, the mere presence of school officers intensifies the situation and increases students' fear that criminal charges may result. ${ }^{102}$ Therefore, officers' presence alone is enough to make a reasonable student believe they are in custody during an in-school interrogation. ${ }^{103}$

If a court finds that a student is under custodial interrogation, voluntariness is not an excuse for withholding Miranda warnings. ${ }^{104}$ Schools cannot avoid the Miranda requirement by arguing that students voluntarily spoke to resource officers. ${ }^{105}$ Miranda's procedural safeguards exist because the voluntariness test proved inadequate when custodial interrogation is involved, due to the inherent lack of free choice. ${ }^{106}$ In Dickerson v. United States, the Court questioned the reliance on the traditional totality-of-the-circumstances test, due to its risk of overlooking an involuntary custodial confession. ${ }^{107}$ Ignoring the realistic maturity differences between children and adults would "deny children the full scope of

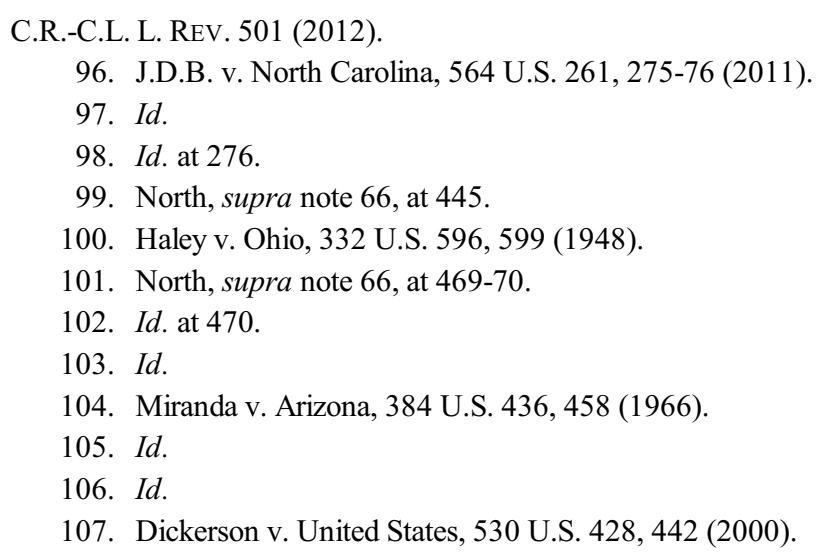


the procedural safeguards that Miranda guarantees to adults." ${ }^{108}$ And as the Court noted in In re Gault, "[i]t would indeed be surprising if the privilege against selfincrimination were available to hardened criminals but not to children." 109

To afford students their rightful constitutional protections, Indiana courts must implement rules that take into account both the increased risk of coercion in the school setting and the reasonable child standard when determining whether a student is in custody for Miranda purposes. ${ }^{110}$ But under Indiana's current standard, established by two recent Indiana Supreme Court decisions, the Miranda rule within schools does not clearly and fully take into account these two issues in the custody analysis. ${ }^{11}$

\section{MIRANDA IN INDIANA SCHOOLS}

On June 20, 2018, the Indiana Supreme Court handed down two decisions that addressed Miranda warnings in Indiana schools. ${ }^{112}$ While this pair of cases demonstrates when a Miranda warning is required before questioning a student and when a warning is not required, the cases do not clearly define a rule for school administrators and school officers to confidently apply when questioning students. ${ }^{113}$ Indiana's ambiguous standard, left unaddressed, is too convoluted for school administrators to apply without feeling required to Mirandize every student that is questioned. If school officials are forced to Mirandize every student before they ask a question, it may inhibit school officials' ability to maintain a safe and orderly educational environment.

Section A discusses the Indiana Supreme Court's decision in B.A. v. State and the implications it has on the custody analysis for Miranda purposes within schools. ${ }^{114}$ Section B focuses on the opposite conclusion at which the court arrived in D.Z. v. State and the agency concern it presents for in-school custody analyses moving forward. ${ }^{115}$

\section{A. B.A. v. State}

After B.A., a thirteen-year-old middle-school student, was adjudicated delinquent based on statements he made during an in-school interrogation regarding a bomb threat on the school's bathroom wall, the Indiana Supreme Court reversed his adjudication due to Miranda warning failures. ${ }^{116}$

Miranda warnings and Indiana's juvenile waiver statute apply when minor

108. J.D.B. v. North Carolina, 564 U.S. 261, 281 (2011).

109. In re Gault, 387 U.S. 1, 47 (1967).

110. See supra Part I.

111. See infra Part II.

112. See D.Z. v. State, 100 N.E.3d 246 (Ind. 2018); see also B.A. v. State, 100 N.E.3d 225 (Ind. 2018).

113. Id.

114. See B.A., 100 N.E.3d at 225 .

115. See D.Z., 100 N.E.3d at 246.

116. B.A., 100 N.E.3d at 225. 
students are under custodial interrogation. ${ }^{117}$ Indiana's juvenile waiver statute allows unemancipated juveniles to waive their Miranda rights only through counsel or a custodial parent, guardian, custodian, or guardian ad litem. ${ }^{118}$ At the time of B.A.'s interrogation, no legal counsel or parent or guardian was present, so under Indiana law, B.A. indisputably did not waive his Miranda rights. ${ }^{119}$

Because B.A. did not waive his Miranda rights, the Indiana Supreme Court applied the totality-of-the-circumstances test to determine that B.A. was under custodial interrogation, and therefore a Miranda warning was necessary. ${ }^{120}$ The court mentioned multiple factors that may be relevant under this test such as the number of officers present and how they are involved, ${ }^{121}$ whether the setting is a traditional school-discipline environment or is police dominated, ${ }^{122}$ what the student is told about the interview, ${ }^{123}$ the length of the interview, ${ }^{124}$ the student's age, ${ }^{125}$ whether the student is arrested after the interview, ${ }^{126}$ and the relationship between the parties, including whether police officers act as teachers, counselors, or law enforcement agents. ${ }^{127}$

Even though no one yelled at or threatened B.A., the consistent police presence was sufficient to place significant coercive pressure on a reasonable student in the same situation. ${ }^{128}$ The officers should have known that the "tagteam probe" was an interrogation, because it was "reasonably likely to elicit an incriminating response." ${ }^{\prime 29}$ And despite B.A.'s youth and the severity of the situation, no one called his mother until the questioning concluded. ${ }^{130}$ Instead, he was left in an unfamiliar, police-dominated situation without support from a parent or counsel. ${ }^{131}$ Most significantly, no one told B.A. that he was free to call his mother, leave the room, or take a break. ${ }^{132}$ B.A.'s case is a prime example of how juveniles can easily succumb to pressure in a custodial interrogation setting, and it demonstrates why there is a need for a clear standard in Indiana schools for administering Miranda warnings. ${ }^{133}$

117. Id. at 231-32.

118. IND. CODE $\S 31-32-5-1$ (2018).

119. B.A., 100 N.E.3d at 234.

120. Id. at 233 .

121. S.G. v. State, 956 N.E.2d 668, 679-80 (Ind. Ct. App. 2011) (finding no custody from one officer's minimal involvement).

122. In re Tyler F., 755 N.W.2d 360, 369 (Neb. 2008).

123. In re C.H., 763 N.W.2d 708, 715 (Neb. 2009).

124. People v. N.A.S., 329 P.3d 285, 289 (Colo. 2014).

125. J.D.B. v. North Carolina, 564 U.S. 261, 277 (2011).

126. Howes v. Fields, 565 U.S. 499, 509 (2012).

127. Minnesota v. Murphy, 465 U.S. 420, 459-60 (1984) (Marshall, J., dissenting).

128. B.A. v. State, 100 N.E.3d 225, 234 (Ind. 2018).

129. Id. (quoting Rhode Island v. Innis, 446 U.S. 291, 301 (1980)).

130. B.A., 100 N.E.3d at 234.

131. Id.

132. Id.

133. See id. at 225. 


\section{B. D.Z. v. State}

In D.Z. v. State, the assistant principal enlisted the school resource officer's help to discover who put sexually explicit graffiti on the high school's bathroom wall. ${ }^{134}$ Seventeen-year-old D.Z. was called to the assistant principal's office after he was identified as the culprit from surveillance video; during this discussion with only the assistant principal, D.Z. admitted to putting the graffiti on the walls. ${ }^{135}$ After his initial confession, the police officer went into the office to talk to D.Z., who confessed again. ${ }^{136}$ The State subsequently filed a delinquency petition alleging that D.Z. committed criminal mischief and harassment. ${ }^{137}$ While both parties agreed that D.Z.'s statements to the officer should be suppressed, because he was never Mirandized, D.Z.'s confession to the assistant principal was admitted and he was found delinquent for committing criminal mischief. ${ }^{138}$

The Indiana Supreme Court found that D.Z. was not entitled to a Miranda warning, because only a school official — not a police officer - interviewed him and there was no evidence of an agency relationship between the vice principal and the school resource officer. ${ }^{139}$ The Indiana Supreme Court noted in Ritchie v. State that school administrators are civilians, and "civilians conducting their own investigation need not give Miranda warnings."140 So, the court held that when police officers are not present during questioning, a clear rule applies - students are neither in custody nor under interrogation, unless school officials are acting as agents of the police. ${ }^{141}$ And since coercion is determined from the student's perspective, any agency relationship implicates Miranda only when the student is so aware of the underlying police involvement that it creates a coercive atmosphere. ${ }^{142}$

While this may seem like a bright-line rule, there are still concerns regarding its fair application. For example, "[t]he police . . . cannot avoid their duty under Miranda by attempting to have someone act as their agent in order to bypass the Miranda requirements." 143 As students continue to see the growing interdependent relationship between school administrators and school officers, who often work together in pursuit of a common goal, the risk of administrators feeling like an agent of the police to students in interviews increases. ${ }^{144}$

Both B.A. and D.Z. highlight flaws in Indiana's current juvenile custodial

134. D.Z. v. State, 100 N.E.3d 246, 247 (Ind. 2018).

135. Id.

136. $I d$.

137. Id.

138. Id. at $247-48$.

139. Id. at 250 .

140. Ritchie v. State, 875 N.E.2d 706, 717 (Ind. 2007).

141. D.Z., 100 N.E.3d at 248.

142. Illinois v. Perkins, 496 U.S. 292, 296 (1990).

143. Sears v. State, 668 N.E.2d 662, 668 (Ind. 1996).

144. North, supra note 66, at 470. 
determination methodology. ${ }^{145}$ While B.A.'s Fifth Amendment rights were ultimately upheld, the court used a lengthy, multi-faceted totality-of-thecircumstances test to arrive at that conclusion. ${ }^{146}$ This test conflicts with the Supreme Court's original intent when deciding to implement Miranda warnings, which was to establish a bright-line, easy to apply rule. ${ }^{147}$ And D.Z. demonstrates how students can still be placed in coercive environments that ultimately result in criminal punishment when speaking to a school administrator alone. ${ }^{148}$ Even without the presence of an officer, the cooperation between school resource officers and school administrators makes it nearly impossible to establish a clear line between what constitutes an agency relationship, which requires Miranda warnings, and what does not. ${ }^{149}$ To combat these shortcomings in Indiana's current methodology, Indiana should look to other states for guidance before implementing a more straightforward rule that addresses the concerns of schools while recognizing students' individual rights and protections.

\section{COMPARING INDIANA’S RULE TO OTHER STATES’ RULES}

The Indiana Supreme Court historically looks to other states that have interpreted similar constitutional issues as persuasive authority. ${ }^{150}$ By analyzing the strengths and weaknesses of other states' interpretations of the Miranda requirement within schools, Indiana can make an informed decision and implement a rule that protects both schools and students. Section A reviews Texas' rule, because its current statutory framework and interpretation of Miranda within schools is similar to Indiana's, making it an easily implemented change if Indiana selects to follow its model. ${ }^{151}$ Section B discusses why Connecticut's statutory protections are beneficial to study as an example of a legislative alternative for Indiana, instead of the judicial options this Note has focused on. ${ }^{152}$ Finally, in Sections C and D, Kentucky and New Mexico take the custodial interrogation analysis one step further by providing an example of a bright-line rule that aims to protect students' constitutional rights. ${ }^{153}$ These states represent multiple regions across the country and demonstrate four alternatives to Indiana's current interpretation of students' Fifth Amendment rights within

145. See supra Part II.

146. See supra Part II.A.

147. Russell L. Weaver, Bright-Line \& Prophylactic Rules: Reflections from Miranda, 50 TEX. TECH L. REV. 33, 33 (2017).

148. D.Z. v. State, 100 N.E.3d 246, 247-48 (Ind. 2018).

149. See supra Part II.B.

150. Hoagland v. Franklin Twp. Cmty. Sch. Corp., 27 N.E.3d 737, 746-47 (Ind. 2015); Allen v. Van Buren Twp. of Madison Cty., 184 N.E.2d 25, 30 (Ind. 1962).

151. Green, supra note 25 , at 169.

152. Id. at 170-71.

153. N.C. v. Commonwealth, 396 S.W.3d 852, 852 (Ky. 2013); State v. Antonio T., 352 P.3d 1172, 1176 (N.M. 2015). 
schools..$^{154}$

\section{A. Texas}

Texas case law employs a two-step analysis, which includes both the totalityof-the- circumstances and reasonable-child tests. ${ }^{155}$ First, the Texas courts assess the totality of the circumstances surrounding the interrogation to determine whether the student's freedom of movement was restricted. ${ }^{156}$ Second, the Texas courts consider whether a reasonable person would have felt at liberty to terminate the interrogation and leave. ${ }^{157}$ This standard keeps in mind that "[a] child is in custody if, under the objective circumstances, a reasonable child of the same age would believe his freedom of movement was significantly restricted." 158 The Texas courts outline a number of situations that generally constitute custody: "(1) when the suspect is physically deprived of his freedom of action in any significant way; (2) when . . . [an] officer tells the suspect that he cannot leave; (3) when law enforcement officers create a situation that would lead a reasonable person to believe that his freedom of movement has been significantly restricted; and (4) when there is probable cause to arrest and the . . officers do not tell the suspect that he is free to leave." ${ }^{159}$ Texas' application is similar to Indiana's use of Miranda's totality-of-the-circumstances test, but Texas statutes and case law emphasize that it is a two-part test that creates an important distinction between the totality-of-the-circumstances test and the reasonable-child test. ${ }^{160}$

\section{B. Connecticut and Colorado}

Connecticut and Colorado both utilize a totality-of-the-circumstances approach to determining custody. ${ }^{161}$ Connecticut's juvenile statute has a totalityof-the-circumstances approach and provides that juveniles under age sixteen must have a parent or guardian present during an interrogation for statements to be used against them. ${ }^{162}$ Connecticut still requires that before any statement by a sixteen- or seventeen-year-old is admissible, the juvenile must have the opportunity to contact a parent or guardian and be afforded Miranda rights. ${ }^{163}$ While Connecticut's statute gives the judge broad discretion to consider how a valid waiver is given by a minor, "when applied in the school setting, the police can argue their 'good-faith belief' that the child was at least eighteen, if not

154. See Green, supra note 25 , at $168-71$.

155. Id. at 168-69.

156. In re D.J.C., 312 S.W.3d 704, 712 (Tex. App. 2009).

157. Id.

158. Id.

159. Dowthitt v. State, 931 S.W.2d 244, 255 (Tex. Crim. App. 1996).

160. Green, supra note 25, at 169.

161. Id. at 170-71.

162. Id.

163. Id. at 171 . 
older." ${ }^{164}$ Both Connecticut's and Colorado's approach allows for a presumptive in-custody approach in schools. ${ }^{165}$ While Connecticut and Colorado apply the totality-of-the-circumstances test as Indiana does, each state has extra, bright-line statutory measures that provide a higher degree of protection for statements made by juveniles during custodial interrogations. ${ }^{166}$

\section{Kentucky}

The Kentucky Supreme Court took the analysis one step further in N.C. v. Commonwealth by finding that the mere presence of a school officer is sufficient to trigger the Miranda warning requirement when the student is subject to criminal charges. ${ }^{167}$ The student in N.C. was under the impression that his interview was regarding a matter of school discipline and had no indication that criminal charges would be filed against him - the exact type of behavior Miranda seeks to prevent. ${ }^{168}$ The court determined that "[n]o reasonable student, even the vast majority of seventeen-year-olds, would have believed that he was at liberty to remain silent, or to leave, or that he was even admitting to criminal responsibility under these circumstances." 169 The court clarified that school officials may freely question students for disciplinary and safety purposes, but any non-Mirandized statements may not be used against a student as a basis for criminal charges when a school officer is involved..$^{170}$

\section{New Mexico}

Like Kentucky, the New Mexico Supreme Court held in State v. Antonio T. that an officer's mere presence while the vice principal asked questions regarding the student's possession of alcohol was sufficient to trigger the Miranda warning requirement, because the officer's presence transformed the meeting into a coercive and adversarial encounter. ${ }^{171} \mathrm{New}$ Mexico provides more protection for students than most states; under New Mexico statute, an officer must Mirandize a juvenile when the child is subjected to an "investigatory detention," a less coercive circumstance than custodial interrogation. ${ }^{172}$ New Mexico provides significantly more safeguards than Indiana, unless the Indiana General Assembly passes new legislation, and it remains a good example of juvenile-centered constitutional protections. ${ }^{173}$

164. Id. at 170 .

165. Id.

166. Id. at 170-71.

167. N.C. v. Commonwealth, 396 S.W.3d 852, 852 (Ky. 2013).

168. Id. at 862 .

169. Id.

170. Id. at 865 .

171. State v. Antonio T., 352 P.3d 1172, 1176 (N.M. 2015).

172. Javier B. Garcia, Miranda Goes to the Principal's Office: State v. Antonio T. and Juvenile Miranda Warnings in Schools, 46 N.M. L. REV. 430, 431 (2016).

173. See id. 
Each state provides a unique interpretation of juveniles' Fifth Amendment rights within schools. For Indiana to follow the example of Colorado, Connecticut, or New Mexico, the Indiana General Assembly would have to pass new legislation that implements additional protections for juveniles' constitutional rights. ${ }^{174}$ But the Indiana Supreme Court can offer a simpler alternative that fits into Indiana's pre-existing juvenile criminal statutes by defining a bright-line standard, similar to the rule the Kentucky Supreme Court established in N.C. v. Commonwealth. ${ }^{175}$

\section{POLICY CONSIDERATIONS FOR IN-SCHOOL POLICING}

There are multiple policy considerations that must be taken into account when dealing with in-school policing as it pertains to students' Fifth Amendment rights, but two stand out: (1) the public safety exception to Miranda, ${ }^{176}$ and (2) the "school-to-prison pipeline." ${ }^{177}$ Section A discusses the necessary public safety exception to the Miranda rule and why it remains an important fixture in the school-setting Miranda analysis. ${ }^{178}$ And Section B examines the rise in the criminalization of common school misbehaviors, known as the "school-to-prison pipeline" and the effect this has on the traditional judicial latitude given to schools. ${ }^{179}$

\section{A. The Public Safety Exception}

When crafting new policies regarding school resource officers, the Indiana legislature and judiciary must remember that the primary goals of student interrogations are to maintain student safety and school discipline. ${ }^{180}$ So, Miranda's key exception - public safety - still applies in schools in cases of imminent danger. ${ }^{181}$ When school officers face a pressing need to secure the safety of students, Miranda warnings may be bypassed. ${ }^{182}$

Determining which situations qualify under the public safety exception requires additional analysis. Imminence is a key deciding factor; for example, in New York v. Quarles, the defendant's un-Mirandized statement about where he placed his gun in the supermarket was admissible under the public safety exception, because the officer had reason to believe that the suspect in an armed rape had just removed the gun from his holster and could pose a danger to the

174. Compare Ind. Code § 31-32-5-1 (2018), with Conn. Gen. Stat. § 46b-137(a) (Supp. 2012), Colo. Rev. Stat. § 19-2-511(1) (2005), and N.M. Stat. AnN. § 32A-2-14 (2009).

175. N.C. v. Commonwealth, 396 S.W.3d 852 (Ky. 2013).

176. New York v. Quarles, 467 U.S. 649, 656-57 (1984).

177. Kim, supra note 6, at 862 .

178. See infra Part IV.A.

179. See infra Part IV.B.

180. Carey, supra note 13, at 579.

181. Quarles, 467 U.S. at 656-57.

182. Id. 
public. ${ }^{183}$ Similarly, in Bailey v. State, the defendant's pre-Miranda statements to police were admissible under the public safety exception, because the officer's questions were asked with the purpose of aiding a battery victim. ${ }^{184}$ As these cases demonstrate, the public safety exception does not always require that the general public be at risk; at minimum, it only requires that the officer be attempting to locate or aid a possible victim. ${ }^{185}$

But there are limits to the public safety exception. ${ }^{186}$ Even though there was a school bomb threat in B.A. - a seemingly serious issue that might meet the public safety exception in other circumstances-school officers and administrators determined that the student body was not in danger at the time of the interview. ${ }^{187}$ Because the situation lacked immediacy and did not threaten the safety of other students, it did not meet the public safety exception threshold. ${ }^{188}$ Schools must cautiously use the public safety exception only in cases of true emergencies; otherwise, schools risk abusing the exemption and promoting the "school-to-prison pipeline."189

\section{B. The School-to-Prison Pipeline}

Schools often struggle with the difficult balance between public needs and students' individual rights. ${ }^{190}$ When parents send their children to school, they rely on the system to provide a clean, safe, scholastic environment that is conducive to learning. ${ }^{191}$ In an effort to protect students, it is easy to see why many schools implement "zero tolerance" policies for drug activity and other serious offenses. ${ }^{192}$ But these policies often cause dramatic shifts away from inschool discipline and instead cause schools to rely more on the juvenile justice system to intervene not only in drug cases, but also in common school misbehavior situations. ${ }^{193}$ This heavy reliance on the juvenile justice system to manage day-to-day misconduct perpetuates what is commonly referred to as the "school-to-prison pipeline." 194

The "school-to-prison pipeline" is contrary to the educational goals that historically insulated school disciplinary practices from intense judicial scrutiny. ${ }^{195}$ Traditionally, courts restricted constitutional rights in schools if the

183. Id. at 657.

184. Bailey v. State, 763 N.E.2d 998, 1001 (Ind. 2002).

185. Id. at 1002 .

186. See, e.g., B.A. v. State, 100 N.E.3d 225, 231 (Ind. 2018).

187. Id.

188. Id.

189. New York v. Quarles, 467 U.S. 649, 656-57 (1984); Kim, supra note 6, at 862.

190. N.C. v. Commonwealth, 396 S.W.3d 852, 863 (Ky. 2013).

191. Id.

192. Id.

193. Id.

194. Kim, supra note 6, at 862.

195. Id. 
constraint could be justified by pedagogical objectives. ${ }^{196}$ While deference to schools remains, administrators and resource officers cannot abuse this courtapproved leeway by depriving students of their constitutional rights if the investigation and punishment of school misconduct no longer serves the accused students' or the student body's educational interests. ${ }^{197}$

When defining bright-line rules for in-school policing, courts must keep these two public policy considerations in mind. ${ }^{198}$ While public safety remains a legitimate exception to the Miranda requirement, schools must use it sparingly and only in cases of imminent danger. ${ }^{199}$ And to avoid promoting a widespread "school-to-prison pipeline," schools should avoid criminalizing common, nonviolent student misbehavior by clearly defining the role of school resource officers in minor disciplinary matters. ${ }^{200}$

\section{ALTERNATIVE BRIGHT-LINE RULES}

The United States Supreme Court repeatedly opts to define bright-line rules in criminal procedure cases. ${ }^{201}$ In Gideon v. Wainwright, the Court abruptly departed from its old, totality-of-the-circumstances model, and declared that indigent defendants have the right to counsel. ${ }^{202}$ And in Argersinger v. Hamlin ${ }^{203}$ and Scott v. Illinois, ${ }^{204}$ the Court clarified Gideon's application with a bright-line rule that afforded indigent defendants counsel when they received a penalty of actual imprisonment for any length of time. Still, Miranda remains the ultimate bright-line rule issued by the Supreme Court. ${ }^{205}$

Because Miranda is such a significant bright-line rule, clearly defining its scope within schools will benefit courts, students, resource officers, and administrators. ${ }^{206}$ Bright-line rules allow the Supreme Court to streamline and more easily control the decisions of the lower federal courts and state courts. ${ }^{207}$ For example, prior to Gideon, courts used a complex and time-consuming totality-of-the-circumstances test to determine if an indigent defendant was entitled to court-appointed counsel; after Gideon, lower courts need only to review the record for two basic questions before making a determination. ${ }^{208}$ This straightforwardness allows the Court to quickly determine whether a lower court

196. Id. at 866 .

197. Id. at 863 .

198. New York v. Quarles, 467 U.S. 649, 656-57 (1984); Kim, supra note 6.

199. Quarles, 467 U.S. at 656-57.

200. Kim, supra note 6 , at 862.

201. Weaver, supra note 147.

202. Gideon v. Wainwright, 372 U.S. 335 (1963).

203. Argersinger v. Hamlin, 407 U.S. 25 (1972).

204. Scott v. Illinois, 440 U.S. 367 (1979).

205. Weaver, supra note 147.

206. Id.

207. Id. at 34 .

208. Id. at 34-35. 
erred. ${ }^{209}$ But the Miranda decision was not only a way to guide lower courts, it was extraordinarily detailed and designed to guide police and other actors within the criminal justice system. ${ }^{210}$ Bright-line rules do not solely benefit the courts; they also simplify the officers' jobs by limiting the analysis and not "burdening police with the task of anticipating the idiosyncrasies of every individual suspect ...." 211 As Peter Price explained, "[b]eing held to a consistent standard will help officers make the type of split-second decisions often required in school disciplinary actions." 212

While it is clear that a bright-line rule would be beneficial to all parties involved in school disciplinary actions, there are six alternatives that Indiana should consider before implementing any changes. ${ }^{213}$ First, school administrators and officers could ignore Miranda warnings entirely and accept that any statement made by students may not be used in a criminal proceeding. ${ }^{214}$ Second, schools could implement policies that allow only school administrators, not officers, to question students. ${ }^{215}$ Third, administrators and officers could both be required to Mirandize students before any interview. ${ }^{216}$ Fourth, the Indiana General Assembly could amend Indiana's juvenile code to provide more statutory protection to students. ${ }^{217}$ Fifth, courts could establish a presumption of custody any time an officer questions a student. ${ }^{218}$ And finally, courts could implement a presumption of custody whenever a student is in the presence of a police officer during interrogations, even if the officer does not ask any questions. ${ }^{219}$

\section{A. Ignore Miranda Warnings}

The first option is for schools to avoid Miranda warnings altogether by limiting any questioning conducted within the school to matters of school discipline only. ${ }^{220}$ In an effort to focus on discipline and the protection of other students, school resource officers could be present and freely participate in interrogations without Mirandizing the student, but as a result, any incriminating statements would likely be inadmissible in a criminal prosecution. ${ }^{221}$ This option

209. Id. at 35 .

210. Id. at 35,40 .

211. J.D.B. v. North Carolina, 564 U.S. 261, 271 (2011).

212. Peter Price, When Is A Police Officer An Officer of the Law?: The Status of Police Officers in Schools, 99 J. CRIM. L. \& CRIMINOLOGY 541, 567 (2009).

213. See Weaver, supra note 147.

214. See infra Part V.A.

215. See infra Part V.B.

216. See infra Part V.C.

217. See infra Part V.D.

218. See infra Part V.E.

219. See infra Part V.F.

220. Carey, supra note 13, at 580.

221. Id. at 579-80. 
presents little to no risk of infringing students' Fifth Amendment rights. ${ }^{222}$ And it accomplishes what should be the primary goal of school administrators' questioning - obtaining the information necessary to maintain a safe and disciplined academic environment. ${ }^{223}$

The main disadvantage this alternative presents is that school officers and law enforcement in general might disagree with school administrators on the end goal of in-school interrogations. ${ }^{224}$ Criminal punishment is a powerful tool in the school's disciplinary tool belt, so officers and administrators might argue that their inability to hold the juvenile responsible for criminal activity will be a detriment to the school's safety and efficiency. ${ }^{225}$ In order to maintain the option to hold students criminally responsible if necessary-while still avoiding the risk of inhibiting the flow of information between students and the school that comes with Miranda warnings - schools could opt for administrator-conducted interviews. ${ }^{226}$

\section{B. School Administrators Solely Conduct Questioning}

Schools could implement a policy that prohibits students from being interrogated about potentially criminal activity with a school officer present. ${ }^{227}$ While this would give school officials the ability to discipline students without implicating Miranda, this policy runs the risk of systematically circumventing students' Miranda protections by having school administrators investigate criminal activity and then turn the evidence over to police. ${ }^{228}$ This practice could lead to a finding of an agency relationship between officials and officers - transforming these scenarios into custodial interrogations that require Miranda warnings. ${ }^{229}$

But courts generally allow a great level of cooperation between police and school administrators before finding an agency relationship, which gives school officers and administrators significant freedom. ${ }^{230}$ Still, courts cannot turn a blindeye to the reality that schools make little effort to deny: "[L]aw enforcement, generally, and school resource officers, specifically, are partners of the administration." ${ }^{231}$ While the potential agency relationship between school officials and officers remains a realistic concern, the court would expand Miranda too broadly if it required civilian school administrators to give students Miranda

222. See id. at 580 .

223. Id. at 579 .

224. See id. at $579-80$.

225. Id. at 579 .

226. Id. at 580 .

227. $I d$. at 579 .

228. Id.

229. Id.

230. Price, supra note 212, at 555-56.

231. Paul Holland, Schooling Miranda: Policing Interrogation in the Twenty-First Century Schoolhouse, 52 LOY. L. REV. 39, 90 (2006). 
warnings before having a conversation with them regarding any disciplinary matter. ${ }^{232}$

\section{Administrators and Officers Must Mirandize Every Time}

A third option is to Mirandize students every time they are questioned in school, regardless of whether it is a school officer or administrator conducting the interview. $^{233}$ While Mirandizing students during every interrogation would alleviate any risk of constitutional violations, this policy may hinder school officials' ability to obtain information that will keep other students safe and maintain school discipline. ${ }^{234}$ Students who might otherwise be willing to speak with the principal or vice principal may no longer be willing to provide the administrator with valuable information after a Miranda warning is given. ${ }^{235}$ Over time, frequent Miranda warnings might dissolve the informal relationship between school administrators and students, causing a more adversarial environment to develop. ${ }^{236}$

Additionally, it is unreasonable and unnecessary to expect a principal or teacher to understand the myriad of legal ramifications that could stem from interviewing a student. ${ }^{237}$ This requirement could lead to the absurd result that a teacher must Mirandize a student before asking a basic question such as, "Did you say a bad word on the playground?"238 Courts should not require that school administrators - civilians who lack formal legal training in criminal procedure-deliver Miranda warnings. ${ }^{239}$ The Supreme Court was clear in Miranda that the warning requirement does not apply to civilians, and there is no persuasive reason to alter this longstanding rule. ${ }^{240}$ It is important to remember that school administrators' paramount job is to promote a safe and productive educational environment ${ }^{241}$; turning principals into what students may view as pseudo-law enforcement officers is not an effective way of reaching that goal. ${ }^{242}$

\section{Amend Indiana's Juvenile Statute}

Many states, including Connecticut, Colorado, and North Carolina, have

232. N.C. v. Com., 396 S.W.3d 852, 864 (Ky. 2013).

233. Garcia, supra note 172, at 441-43.

234. Carey, supra note 13, at 579.

235. Garcia, supra note 172, at 445.

236. Id.

237. N.C., 396 S.W.3d at 864.

238. See New Jersey v. T.L.O., 469 U.S. 325, 339-40 (1985) (“[W]e have recognized that maintaining security and order in the schools requires a certain degree of flexibility in school disciplinary procedures, and we have respected the value of preserving the informality of the student-teacher relationship.").

239. Garcia, supra note 172, at 443 (2016).

240. See Miranda v. Arizona, 384 U.S. 436, 444 (1966).

241. Carey, supra note 13, at 579.

242. Garcia, supra note 172 , at $442-43,445$. 
enacted Miranda statutes that generally exclude a child's statements made during custodial interrogation, unless they are offered in the presence of a trusted adult, legal guardian, or attorney. ${ }^{243}$ While some of these statutes limit the exclusion of statements by age, other protections are still provided for juveniles above the age limit. ${ }^{244}$

Connecticut and North Carolina define an age-limit for this additional statutory protection, but a seventeen-year-old is arguably just as vulnerable to constitutional violations as a thirteen-year-old. ${ }^{245}$ While it is true that a thirteenyear-old and seventeen-year-old have much different education and maturity levels, they are both juveniles under the law, meaning they are often treated as equivalents. ${ }^{246}$ And while society gives seventeen-year-olds more responsibility, such as a driver's license and the ability to work a job, scientific research on adolescent brain development shows no difference in impulse control, sensation seeking, resistance to peer influence, future orientation, and risk perception between ten-year-olds and seventeen-year-olds. ${ }^{247}$ This comparable lack of psychosocial maturity is exactly what makes juveniles - whether they are thirteen or seventeen - highly susceptible to custodial interrogations. ${ }^{248}$ And this is why multiple states choose to provide additional safeguards alongside Miranda warnings to ensure minors' Fifth Amendment rights are protected. ${ }^{249}$

Although phrased differently, these statutes generally have the same effect as Indiana's current juvenile waiver statute, which requires the presence of counsel or a custodial parent, guardian, custodian, or guardian ad litem before a minor may waive his Miranda rights. ${ }^{250}$ The biggest difference between the Connecticut, Colorado, and North Carolina statutes and Indiana's statute is the time when the constitutional protection begins. In Indiana, Miranda rights have to be given first, before a juvenile can even contemplate waiving them in accordance with the waiver statute. ${ }^{251}$ But in Connecticut, Colorado, and North Carolina, the statutory protection begins whenever the juvenile is in custody. ${ }^{252}$ The fact that minors are protected from admissions whenever they are in custody

243. Green, supra note 25 , at 171.

244. Id.; N.C. GEN. STAT. § 7B-2101(a)(3), (b) (2011) (North Carolina limits this protection to children under sixteen years old); CONN. GEN. STAT. § 46b-137(a) (Supp. 2012) (Connecticut limits this provision to children under sixteen years old).

245. Green, supra note 25 , at 171.

246. Juvenile is defined as "[a] person who has not reached the age (usu. 18) at which one should be treated as an adult by the criminal-justice system; MINOR." Black's Law Dictionary 945 (9th ed. 2009).

247. Joseph M. Peraino \& Patrick J. Fitz-Gerald, Psychological Considerations in Direct Filing, 40 Colo. LAW. 41, 43 (2011).

248. Id.

249. Green, supra note 25 , at 171.

250. Ind. Code. $\S 31-32-5-1$ (2018).

251. $I d$.

252. Conn. Gen. Stat. § 46b-137(a) (Supp. 2012); Colo. Rev. Stat. § 19-2-511(1) (2005); N.C. Gen. StAT. § 7B-2101(a)(3), (b) (2011). 
allows students to be shielded under the statute in situations where they are deemed to be in custody, even though a school administrator (instead of an officer) conducted the interrogation. ${ }^{253}$

While this might seem like a small nuance, it is a gap that the Indiana General Assembly should take into consideration in its juvenile statute. ${ }^{254}$ However, there may be simpler alternatives that afford students the same Fifth Amendment protection without an act of legislation. ${ }^{255}$

\section{E. Presumption of Custody Anytime an Officer Questions}

Another bright-line option is to consider students presumptively in custody, signaling the requirement of a Miranda warning, whenever police question children in school. ${ }^{256}$ Or at minimum, the custody threshold should be lowered in school settings. ${ }^{257}$ This test is not meant to deter school resource officers from doing their jobs. ${ }^{258}$ In fact, the Indiana Supreme Court emphasized in B.A. that its decision does not mean that school resource officers must completely avoid placing students under custodial interrogation-students sometimes commit crimes that require investigation - but school officers must give Miranda warnings and follow Indiana's juvenile waiver statute when conducting such interviews. ${ }^{259}$

Still, the Indiana Supreme Court may have been intentionally vague, potentially in an effort to give educators some leeway. ${ }^{260}$ The court noted that a bright-line rule for custody would be easier for schools, police, and courts to apply. ${ }^{261}$ But, the court still declined to establish a bright line, stating that such a rule would fail to account for the nuances of each case that Miranda's totality-ofthe-circumstances test requires. ${ }^{262}$

\section{F. Presumption of Custody in the Mere Presence of an Officer}

The final alternative Indiana should consider is the presumption of custody during questioning in the mere presence of an officer, regardless of whether the officer utters a word. ${ }^{263}$

The highest courts in Kentucky and New Mexico found this a viable solution

253. Id.

254. Compare Ind. Code. § 31-32-5-1 (2018), with Conn. Gen. STAT. § 46b-137(a) (Supp. 2012), Colo. Rev. Stat. § 19-2-511(1) (2005), and N.C. GEN. StAT. § 7B-2101(a)(3), (b) (2011).

255. See infra Parts V.E., V.F.

256. Green, supra note 25 , at 171 .

257. North, supra note 66, at 444.

258. See B.A. v. State, 100 N.E.3d 225, 231 (Ind. 2018).

259. Id.

260. See D.Z. v. State, 100 N.E.3d 246 (Ind. 2018); B.A., 100 N.E.3d at 225.

261. B.A., 100 N.E.3d at 233.

262. $I d$.

263. See, e.g., N.C. v. Com., 396 S.W.3d 852, 865 (Ky. 2013); State v. Antonio T., 352 P.3d 1172, 1176 (N.M. 2015). 
to the increased risk of coercion that an officer's presence has over a reasonable child. ${ }^{264}$ To address the increased risk of coercion and intimidation that juveniles often experience in the presence of law enforcement, the Indiana Supreme Court should hold that anytime a student is questioned in the presence of a school officer-even if the officer remains silent - the student is presumed to be in custody for purposes of the Miranda custodial interrogation analysis. ${ }^{265}$

This rule would not place an undue burden on the school or resource officers, especially "when measured against the consequences the child faces in the juvenile justice system or the adult criminal system, which clearly can be punitive." ${ }^{266}$ Unlike civilian administrators, whom cannot be expected to know the inner workings of the Miranda rule, school officers are trained law enforcement agents that know how to give Miranda warnings and how to ensure that the school administrator and the student are aware of when criminal charges may be triggered. ${ }^{267}$ And unlike the option of simply ignoring Miranda within schools, this rule maintains the school's option to file a criminal complaint if administrators believe the misbehavior requires legal action. ${ }^{268}$

Still, there often remains a blurry line between disciplinary and criminal matters. ${ }^{269}$ In those scenarios, the determination should be left up to school officials. ${ }^{270}$ But the court should help make this decision easier for administrators by encouraging them to keep matters of school discipline limited to the school and out of the juvenile justice system. ${ }^{271}$ This is not to say that school resource officers cannot assist school officials; in fact, they are encouraged to provide support. ${ }^{272}$ But if there is even an inkling that a disciplinary issue might develop into a criminal matter, school officers must be aware that any statements made in their presence cannot be used against the juvenile in a criminal proceeding, unless the student was Mirandized and validly waived his rights under Indiana's juvenile waiver statue. ${ }^{273}$ As the Kentucky Supreme Court aptly stated, "Administering school discipline does not require the participation of law-enforcement. Administering the law does." ${ }^{274}$

\section{CONCLUSION}

In Miranda v. Arizona, the Supreme Court introduced a bright-line rule that

264. See N.C., 396 S.W.3d at 865; Antonio T., 352 P.3d at 1176.

265. See N.C., 396 S.W.3d at 865; Antonio T., 352 P.3d at 1176.

266. N.C., 396 S.W.3d at 865 .

267. $I d$.

268. Id.

269. $I d$. at 864 .

270. See id. at 865 .

271. Id.

272. B.A. v. State, 100 N.E.3d 225, 231 (Ind. 2018).

273. See, e.g., N.C. v. Com., 396 S.W.3d 852, 865 (Ky. 2013).

274. Id. at 864 . 
was intended to be simple for law enforcement officers to apply. ${ }^{275}$ But the most recent Indiana Supreme Court instruction muddied the waters for Miranda's application in schools. ${ }^{276}$ Currently, Indiana - along with other states-has struggled to define custodial interrogation within schools. ${ }^{277}$ As a result, students' constitutional rights are suffering and school administrators and officers are unable to confidently apply the Miranda rule. ${ }^{278}$ While no solution is perfect, one thing is certain - Indiana needs a more straightforward test that school resource officers and administrators can confidently apply when deciding whether a Miranda warning is necessary within schools.

To combat the pressure that students feel in the presence of law enforcement and the unique risk of coercion that is present in the schoolhouse setting, the Indiana Supreme Court should find that students are presumptively in custody for the Miranda analysis when they are questioned in the presence of a school officer. ${ }^{279}$ Even when the officer does not conduct the interview, the mere presence of law enforcement heightens the intimidating nature of the interview to a level where no reasonable child would feel free to leave. ${ }^{280}$

While the straightforward presumption of custody is easy to apply in cases where an officer is present, there is still some confusion when a school administrator is alone but potentially questioning the student as an agent of police ${ }^{281}$ In this case, the Indiana Supreme Court should apply a reasonable child standard when determining whether the student perceived the school administrator to be working in tandem with school officers. ${ }^{282}$ Science confirms the presumption that courts and legislators have relied on for years-minors cannot be analyzed under the same reasonable person standard that is applied to adults. ${ }^{283}$ Instead, juveniles require a different, "reasonable child" standard that takes into account the implications that their immaturity and brain development have on the way they perceive the legal system. ${ }^{284}$ It is important for the Indiana Supreme Court to recognize this as a clear and distinct standard that is applied to juveniles. ${ }^{285}$

The Kentucky Supreme Court got it right when it defined an easy to apply, bright-line rule for school administrators and officers handling disciplinary matters. ${ }^{286}$ Not only does this definitive rule make in-school discipline more

275. See Miranda v. Arizona, 384 U.S. 436 (1966).

276. See D.Z. v. State, 100 N.E.3d 246 (Ind. 2018); B.A., 100 N.E.3d at 225.

277. Green, supra note 25, at 145.

278. Thurau, supra note 2.

279. See, e.g., N.C. v. Com., 396 S.W.3d 852, 865 (Ky. 2013); State v. Antonio T., 352 P.3d 1172, 1176 (N.M. 2015).

280. See, e.g., N.C., 396 S.W.3d at 862.

281. See supra Part V.B.

282. See supra Part I.B.

283. See id.

284. See supra Part I.B.2.

285. See supra Part I.B.

286. See N.C. v. Com., 396 S.W.3d 852 (Ky. 2013). 
straightforward, it also expands students' Fifth Amendment rights by requiring that "when that questioning is done in the presence of law enforcement, for the additional purpose of obtaining evidence against the student to use in placing a criminal charge, the student's personal rights must be recognized." ${ }^{.87}$ Indiana should follow suit and implement a distinct rule that requires students to be Mirandized before any statements made in the presence of a school officer may be used against them in a criminal matter. ${ }^{288}$ This solution returns to the longstanding idea that schools should be focused on education and safety-not on the prosecution of crimes. ${ }^{289}$

With the increasing police presence in schools and the heightened risk of infringement upon students' Fifth Amendment rights against self-incrimination, Indiana must remedy its current ambiguous standard for determining whether a Miranda warning is required during an in-school custodial interrogation. ${ }^{290}$ Two clear rules should apply. First, when only a school administrator is present, a "reasonable child" standard should apply to the custody analysis to determine whether a reasonable child would perceive the administrator to be working in concert with school officers. ${ }^{291}$ And second, in the mere presence of an officer, regardless of whether the officer conducts the interrogation, students should be considered presumptively in custody for Miranda purposes. ${ }^{292}$ These clear-cut standards will remedy the blurry application of the bright-line Miranda rule in Indiana, making school administrators' and officers' jobs easier, while protecting those most at risk from Miranda warning failures - students and their constitutional freedoms. ${ }^{293}$

287. Id. at 864 .

288. See, e.g., id. at 852.

289. See Kim, supra note 6, at 861.

290. See supra Introduction.

291. See supra notes $279-82$ and accompanying text.

292. See supra notes $284-87$ and accompanying text.

293. See supra Introduction. 